\title{
The Effect of Government Subsidy on Non- Technological Innovation and Firm Performance in the Service Sector: Evidence from Germany
}

Shoaib Abdul Basit, Thomas Kuhn

Faculty of Economics and Business Administration, Technische Universität Chemnitz, Germany

Mumtaz Ahmed

Department of Management Sciences, COMSATS Institute of Information Technology, Islamabad, Pakistan

\section{Abstract}

Background: To enhance the innovation activities at the firm level, government subsidies plays an important role. Objectives: The objective of the study is to explore whether firms in service sector that receive government subsidies engage more in marketing and organizational innovation activities than their counterparts. Second, focusing on the subsidized firms in the service sector, the impact of innovations (marketing as well as organizational) on firm performance-measured as the probability of submitted copyright applications by firms, has been analyzed. Methods/Approach: The propensity score matching approach and probit model have been used to analyze the innovation activities of subsidized and non-subsidized firms. The empirical analysis is based on the micro level data from Mannheim Innovation Panel, covering the Community Innovation Survey of 2011. Results: Empirical results show that public subsidy has a significant positive effect on marketing and organizational innovation. In addition, within the firms that have received government subsidy, the impact of only marketing innovation is found to be significant on firm performance. Conclusions: These findings employ that subsidized firms are more likely to perform better than their counterparts. Furthermore, public subsidy programs increase the probability of applying for a copyright in small and medium firms.

Keywords: marketing and organizational innovation; firm performance; subsidy; propensity score matching; kernel matching; nearest neighbor matching; radius matching

JEL classification: 03,030

Paper type: Research article

Received: Jan 20, 2018

Accepted: Feb 13, 2018

Citation: Abdul Basit, S., Kuhn, T., Ahmed, M. (2018), "The Effect of Government Subsidy on Non-Technological Innovation and Firm Performance in the Service Sector: Evidence from Germany", Business Systems Research, Vol. 9, No. 1, pp. 118-137.

DOI: 10.2478/bsrj-2018-0010 


\section{Introduction}

Government funding policy for Research and Development (R\&D) and innovation activities is an important phenomenon in most of the countries. The role of government to provide subsidy for business innovation is very influential because of technological innovation that contributes to growth in national competitiveness (Kim et al., 2016). In modern economies, most of the countries have decided to correct for the existence of market failure by assisting business financed R\&D through direct as well as indirect grants.

Several studies have shown the positive relationship between subsidy and innovation (Buson Piquer, 1991; Fernández et al., 1995). Hall et al. (2009) point out that subsidy recipient firms boost the R\&D effort. In addition, product innovation positively effects the firms' labor productivity while process innovation has a bigger impact through the associated investment. Li et al. (2010) analyze the Chinese provincial panel data for the years 2001-2008 and find that public R\&D subsidies have a significant interval effect on firm's innovation performance. Some scholars argue that government supports to enhance firm innovation activities by providing soft loans, tax incentives and subsidies and it encouraging to the increased innovation activities at firm level (Beugelsdijk et al., 2002; Romijn et al., 2002; Souitaris, 2002 among others).

Most of the studies on innovation have focused on the manufacturing sector e.g., Haned et al., (2014) for France; Czarnitzki et al., (201 1) for Canada; Becker et al. (2004) for Germany; Hussinger (2008) for Germany; Almus et al. (2003) for Germany; Peters et al., (2013) for Germany; Arvanitis et al. (2013) for Switzerland; Cozza et al. (2012) for Italy; Carboni (2017) for European countries including Germany, Austria, Uk, Italy, France, Spain and Hungary. Moreover, Becheikh et al. (2006) provide a review of existing literature on innovation in manufacturing sectors over the period 1993 to 2003 and claim that around $81 \%$ of the existing studies on this subject either focused on product or on process or on both types of innovation activities.

A major part of the literature focuses on analyzing the impact of government subsidies on innovation in general, however, only few studies on this subject are available for the service sector. For instance, Czarnitzki et al. (2001) identify the relation among public R\&D grants and innovation activities of German service firms and propose that innovation activities increase the company's success in applying for future R\&D grants. However, the issue of marketing and organizational innovation in the service sector has not been considered. Later, Czarnitzki et al. (2002) examine the impact of innovation subsidies in German service sector and find that the recipients of innovation funding's have a remarkably higher innovation concentration as compared to non-recipients. Further, findings reveal that, on average, the innovation intensity of subsidized firms is almost six percentage points higher than that of nonsubsidized firms. Similarly, Liu et al. (2016) analyze the effects of different public subsidies including regional, national, and European funded programs on both product and process innovation and on export performance by considering small and medium enterprises in German manufacturing and service sectors. Using a panel data from Mannheim Innovation Panel (MIP) over the period 2001-2014, Liv et al. (2016) find that government financial support gives a higher innovation output, and in later years this reserved into an increase rate of export success. However, this relationship required the certain types of government support and it holds for some specific types of innovation output. Le et al. (2016) point out that R\&D grant recipient firms from manufacturing and service sectors significantly increase the probability of patent applications during 2005 and 2009, however, no positive effect on trademark applications is found. Recently, Kim et al. (2016) reveal that in-house R\&D activities are crucial factors in case of product innovation for both large as well as small medium 
enterprises in the Korean service sector suggesting that the government support program has a remarkable impact on product innovation.

From the thorough review of literature, it is observed that the impact of public subsidy on marketing and organizational innovation has been completely ignored in the existing literature, in particular with regard to the role of marketing and organizational innovation for the service sector. This motivates us to dig out this issue by providing a deeper analysis on firms that receive subsidies by focusing particularly on firms in the service sector. Specifically, the objective is to know if firms that receive subsidy engage more in marketing and organizational innovation activities than nonsubsidized firms. In addition, the impact of marketing as well as organizational innovation on firm performance (taking copyright as a proxy for firm performance) will be analyzed. To our knowledge this is the first study taking into consideration copyright as a proxy for the measurement of firm performance in the service sector. The empirical analysis is carried out using Mannheim Innovation Panel 2011 survey data and making use of probit and propensity score matching method (PSM). The treatment effects of public subsidy are estimated by comparing treated firms (the firms that receive subsidy) with untreated (the firms that do not receive subsidy). In addition, a probit model is used to access the effect of marketing and organizational innovation on copyright applications in services industries.

The remaining paper is laid as follows:

Section 2 provides the literature review while section 3 discusses the econometric approach, data, and descriptive statistics of key variables used in the analysis. Section 4 elaborates the empirical results while the last section describes the concluding remarks and some policy implications.

\section{Literature review}

The government role in providing subsidies for business innovation is influential because technological innovation contributes to growth and national competitiveness (Branstetter et al., 2002; Kim et al., 2016; Le et al., 2016). Romer (1989) considers innovation as an essential source of economic growth.

Nowadays, services play a key role in the economic development. Duchene et al., (2009) reveal that in the United States (US) and Europe (EU), the share of services is almost three quarters of total value added and it is still growing. In fact, a structural shift is observed from manufacturing to services in five economies including Poland, Slovak Republic, Czech Republic, Slovenia and Hungary (Hanzl-Weiss et al., 2010). Some other studies point out that due to relation of their competitiveness and profitability, the importance of service innovation has increased (see for example, Cainelli et al., 2004; Van Riel et al., 2004; Elche et al., 2008, among others).

Public subsidy for research and development is a representative incentive to enhance innovation activities at the firm level (Herrera et al., 2008). Further, Bérubé et al. (2009) reveal that those Canadian firms that benefit from research and development grants as well as tax credits perform better in innovation activities (especially introduced the new goods to the market) than those firms that get benefit from R\&D tax credits only. Similarly, Czarnitzki et al. (2011) elaborate that R\&D tax credit has a positive impact on the number of improved products that introduced by the beneficiary firms in Canada. Bozic et al. (2016) compare the determinants of innovation activities of Croatian manufacturing and service SMEs and find that the recipients of public funding engage more into the product innovation in services SMEs than manufacturing SMEs while the public funding recipients from the manufacturing SMEs engage more in process innovation. Wang et al. (2017) analyze the impact of state innovation funding programs by the Chinese government on firm performance 
and find that grant recipient firms survive longer and do more patent than nonrecipients.

Considering previous studies, many scholars demonstrate that public subsidy has a positive influence on product or process innovation (see Czarnitzki et al., 2011; Kim et al., 2016; Bérubé et al., 2009; Hall et al., 2009). Le et al. (2016) point out that R\&D grant recipients increase the probability that a firm introduces new goods or services into the world market whereas its impacts on product and process innovation are comparatively weaker. It is argued that public subsidy has a significant impact on nontechnology innovation (organizational and marketing innovation).

Thus, based on the existent literature, following hypotheses are proposed and tested empirically:

\section{Hypothesis 1}

"Service firms that receive public subsidy engage more in marketing and organizational innovation activities than non-subsidized firms".

Government policy in terms of support to innovation is very influential for SMEs to become and remain innovative. Without the government support, SMEs are incapable to do innovation (Keizer et al., 2002). It is important to explore the impact of government policy on firm innovation performance. Bronzini et al. (2016) analyze the effect of R\&D subsidy programs in northern Italian regions on the innovation activities of subsidized firms. They find that subsidy programs have remarkable effect on the number of patenting applications of subsidized firms. Similarly, Czarnitzki et al. (2006) investigate the effect of public R\&D grants on firms' innovation activities in Germany and suggest that subsidy has a positive influence on firms' patenting activities. Czarnitzki et al. (2014) examine the two different sources of funding (such as national as well as European funding) impact on innovation input and output of German firms and notice that both funding sources including national and European grants enhance to a considerable innovation input in the economy. In case of innovation output subsidized firms are more active patentees as well as more likely to file a patent. In addition, Doh et al. (2014) investigate the public funding on innovation activities in small and medium enterprises in South Korea and show that a positive relation among technological development assistance by the Korean government and innovative design registration as well patent acquisition of SMEs exists.

Moreover, Sandvik et al. (2003) analyzes that market innovation has a positive impact on firm sales and growth. Similarly, Otero-Neira et al. (2009) also discover that market innovation has a positive influence on business performance. Further, Polder et al. (2010) reveal that for economic and commercial success, organizational innovation plays a key role. According to Lam (2005), organizational innovation is an essential pre-condition of technological (product and process) innovation. Lokshin et al. (2008) suggest that organizational innovation boost the creativity and flexibility of firms and assists the progress of technological innovations. Johne et al. (2000) reveal that marketing innovation enhances sales by increase in demand for product consumption and this factor leads to an additional profit towards firms.

Note that, all studies mentioned above claim that R\&D subsidy has a significant effect on firms' patent and innovation activities but do not provide any evidence on the effect of public R\&D subsidies on copyright application activities of the firms. Additionally, most of the studies discuss about the effect of non-technological innovation on firm performance, sales, and/or technological innovation. However, none of these existing studies has focused on examining the impact of nontechnological innovations on firm performance in terms of probability of submitted 
copyright applications. This is what is considered in this study and the same issue is tested by formulating the following hypothesis:

\section{Hypothesis 2}

"Within the subsidized firms in the service sector, marketing as well as organizational innovation are positively associated with firm performance as compared to nonsubsidized firms".

In the existing literature, several studies use the number of patents and/or registered patent applications as a proxy to measure Innovation output or firm performance (Albors-Garrigos et al., 2011 1). Patent is a specific type of intellectual property right (IPR) usually used as a protection to the innovation. In addition, patents give a right on the creation of new work. It is difficult for a firm to get a patent and it is a costly as well as time consuming process. Rogers (1998) discusses the definition and measure of innovation at firm level, pointing out that a firm can use a patent up to 20 years. Copyright is also another type of IPR used to protect the original work of an inventor. Copyright applies automatically and legally protects the inventor normally till 50 years (Rogers, 1998). Moreover, there is no need of registration of copyrights. For instance, copyright could be applied automatically on work, music, software, piece of written paper etc.

The present study focuses on the service sector firms only. Since the service sector includes several key industries including: "Whole Sale Services, Transport/Post Services, Media Services, IT Services, Financial Services, Technical Services, Business Services, R\&D services, Firm Related Services, Banking and Insurance" and most of the service firms use copyrights to protect their innovation or creation of new work. So, the present study has a valid reason to use copyright as a measure of firm performance.

\section{Methodology}

Two routes are adopted to test each hypothesis. More specifically, the first hypothesis requires one to estimate the differences in outcomes among recipients of the government subsidies and non-recipients of subsidies. In the empirical analysis, in order to assess the public subsidy effect, it's very important to avoid the potential selection bias. Various econometrics methods can be applied to avoid the selection bias, including difference in difference (DID) estimation method, instrumental variables (IV) as well as matching method and selection model as well. However, the DID estimation cannot be applied for cross-sectional dataset. To correlate the treatment variables not the output variables, IV methods as well as selection methods require instrumental variables. Keeping the above mentioned points into account, the present study applies the matching method introduced by Rosenbaum et al. (1983) and developed by Heckman et al., $(1997,1998)$. It is an advantage that a specific function form is not needed to be assumed in matching method while the addressing of endogeneity problem. To test the second hypothesis, probit regression is applied. This is because our output variable (copyright application) in the second hypothesis is a binary variable, so in this case Probit regression is the suitable method.

\section{Matching Method}

Following Caliendo et al. (2008), the matching approach is described as follows:

In a binary variable, the treatment indicator $B_{i}$ equals ' 1 ' if firms receive public R\&D subsidy and ' $O$ ' if firms do not receive public R\&D subsidy. For each individual firm ' $i$ ', the potential outcomes is $Y_{i}\left(B_{i}\right)$. In this paper, $Y_{i}$ is used in two different forms: (i) 
marketing innovation, and, (ii) organizational innovation. The treatment effect is described for every individual firm ' $i$ ' as follows:

$$
\tau_{i}=Y_{i}(1)-Y_{i}(0) \text {. }
$$

It is important to note that the counterfactual outcome, $Y_{i}(0)$, cannot be observed. Hence, estimation of $\tau_{i}$ is not possible and thus the estimation of average treatment effect (ATE) is needed. ATE shows the difference among the recipient and nonrecipient expected outcomes.

$$
\tau_{A T E}=E\left[Y_{i}(1)-Y_{i}(0)\right]
$$

It is important to note that, ATE covers those firms as well for which there was no intention of implementing the program, and thus this measure may not be relevant. Thus, a new measure is needed that can estimate the impact on those firms for which the program is actually proposed. This new measure is called average treatment effect on treated (ATT) and can be explained as:

$$
\tau_{A T T}=E\left[Y_{i}(1) \mid B=1\right]-E\left[Y_{i}(0) \mid B=1\right]
$$

Note that, in (3) above, $E\left[Y_{i}(0) \mid B=1\right]$ cannot be observed being the counterfactual mean. But one can generate the selection bias, (last two terms in equation 4 below), via $E\left[Y_{i}(0) \mid B=0\right]$, given as:

$$
E\left[Y_{i}(1) \mid B=1\right]-E\left[Y_{i}(0) \mid B=0\right]=\tau_{A T T}+E\left[Y_{i}(0) \mid B=1\right]-E\left[Y_{i}(0) \mid B=0\right]
$$

When the selection bias is zero, $\tau_{A T T}$ can be estimated accurately. The condition of zero selection bias does not hold in non-experimental studies, though it holds true in random experiments. To overcome the selection bias problem, conditional independence assumption (CIA) is needed and it is suggested by Rubin (1974). CIA presumes independence of potential outcomes and recipients for firms that have the same exogenous variables $X$ (those variables that potentially affect the receiving of public R\&D support). The following expression grants permission of replacing counterfactual outcome for non-recipient's outcome when CIA holds (provided there does not exist any systematic difference between non-recipient and recipient):

$$
E\left[Y_{i}(0) \mid B=1, X\right]=E\left[Y_{i}(0) \mid B=0, X\right]
$$

This leads us to re-write equation (3) as:

$$
\tau_{A T T}=E\left[Y_{i}(1) \mid B=1, X=x\right]-E\left[Y_{i}(0) \mid B=0, X=x\right] .
$$

As discussed above, in the present paper, $Y_{i}$ is used in two different forms, a) marketing innovation b) organizational innovation. The ATT for $Y_{1}$ (marketing innovation) as well as $Y_{2}$ (organizational innovation) is given in equation (7) and (8) below:

$$
\begin{gathered}
\tau_{1 A T T}=E\left[Y_{1 i}(1) \mid B=1, X=x\right]-E\left[Y_{1 i}(0) \mid B=0, X=x\right] \\
\tau_{2 A T T}=E\left[Y_{2 i}(1) \mid B=1, X=x\right]-E\left[Y_{2 i}(0) \mid B=0, X=x\right]
\end{gathered}
$$


The Matching Method approach (Rubin, 1974) is chosen to be used to analyse the difference in outcomes of non-recipients and recipients. Rosenbaum et al. (1983) propose the usage of the balancing property score approach to build a valid control group in case of several variate as in this case. Generally, it is not possible to match recipients and identical non-recipients. The present study uses three popular matching methods: a) kernel matching, b) nearest-neighbor matching, and c) radius matching. Kernel matching is a non-parametric approach which use the weighted average of all observations in the non-recipient (control group) to construct the counterfactual outcome. Kernel matching requires to select the kernel function as well as the bandwidth-the former is relatively less important than the latter which is crucial due to the trade-off among variance and bias of estimates, while small variance and large bias are induced in high bandwidth. The Epanechnikov's kernel function with 0.05 as bandwidth is used to match the recipients with the control group (the subsidized vs. non-subsidized firms). The nearest-neighbor matching identifies the nearest firms on the bases of propensity score. Selection of $K$ imposes a tradeoff between bias as well as variance, where greater $k$ guide to small variance and big bias. Based on previous literatures we select $k=7$. In radius method bad matches could be prevented through the selection of the level of tolerance at the maximum propensity score range and we use 0.05 as the level of tolerance. In the existing literature, no clear-cut matching method is superior, therefore, the empirical analysis is carried out through using three matching methods, and a comparison is also provided. The results of the propensity score matching method (kernel, nearest neighbor and caliper) retrieved from the probit model are provided in Table 4-5 for small as well as for medium firms.

\section{Data and its Sources}

Table 1

Definition of Variables

\begin{tabular}{l|l}
\hline Variable & Measurement \\
\hline Marketing Innovation & 1 if firm introduces marketing innovation and 0 otherwise \\
\hline $\begin{array}{l}\text { Organizational Innovation } \\
\text { Public R\&D Subsidy }\end{array}$ & 1 if firm introduces organizational innovation and 0 otherwise \\
\hline Copyright Application & 1 if firm receives local, national, EU and 0 otherwise \\
\hline Graduate Employee & 1 if number of graduate employees are less than 100 and 0 otherwise \\
\hline Small Firms & 1 if firm has less than 50 employee and 0 otherwise \\
\hline Medium Firms & 1 if firm has 50 to 249 employees and 0 otherwise \\
\hline Large Firms & 1 if firm has 250 or more employees and 0 othewise \\
\hline National market & 1 if firm performs in national market environment and 0 otherwise \\
\hline Eastern Germany & 1 if firm is placed in Eastern part of Germany and 0 otherwise \\
\hline Whole Sale Services Firms & 1 for whole sale firms and 0 otherwise \\
\hline Transport/Post Services & 1 for transportation service firms \& 0 otherwise \\
\hline Media Services & 1 for Media service firms and 0 otherwise \\
\hline IT Services & 1 for IT service firms and 0 otherwise \\
\hline Finance Services & 1 for finance service firms \& 0 otherwise \\
\hline Technical Services & 1 for technical service firms and 0 otherwise \\
\hline Business Services & 1 for business service firms and 0 otherwise \\
\hline
\end{tabular}

Source: Authors' work 
The present study uses micro data of German service sectors firms from 2011 Mannheim Innovation Panel (MIP) survey organized by the Centre of European Economic Research (ZEW) with the cooperation of the German Ministry of Education and Research (BMBF). MIP survey collects information on innovation activities and R\&D and it asks from the respondent firms if they have received any government funding for innovation as well as various sources of funding. All types of public R\&D subsidies such as local, national, federal and EU level are considered. The analysis is done on subgroups of firms (small, medium and large) to get a deeper picture at the firm level. The discussion of relevant variables is provided in Table 1.

\section{Dependent and Independent Variables}

The present study contains two parts of analysis one for each of hypothesis 1 and hypothesis 2 . In the first part of analysis, the organizational innovations as well as marketing innovations are taken as dependent variables while subsidy is considered as an independent variable. For the second part of our analysis, firm performance is considered as a dependent variable, measured as the probability of submitted copyright application by firms due to new methods of marketing innovation or new organizational methods, while marketing and organizational innovation are independent variables.

\section{Control Variables}

Firm specific control variables are essential to properly separate the casual effect of R\&D subsidy. In analysis, several control variables are used that might have an impact on the outcome variables stated above. Several basic variables are used as controls including firm size on the base of total employment and number of graduate employees following Reinkowski et al. (2010), firm geographical market location following (Almus et al., 2003) and Eastern Germany as an additional control to analyze the impact of the reunification of Germany in 1990. Due to a change from the planned economy to the market economy, Eastern German companies get benefits from special conditions in case of government support (Czarnitzki et al., 2014). Finally, several service industry dummies are also included as controls (see Table 1 for detailed discussion and construction of these control variables).

\section{Descriptive Statistics}

Table 2 presents the descriptive statistics for public subsidy recipients and nonrecipients in small medium and large firms in the service sector. It is noted that in subsidized firms, the average of marketing innovation, organizational innovation and copyright application are higher as compared to non-subsidized firms. The difference in average may be due to the selection bias which must be corrected while assessing the public subsidy effects.

Further, Table 2 shows the remaining variables as exogenous covariates $X$. In order to fulfil the conditional independence assumption, covariate $X$ should contain those variables that have potential effect on receiving the subsidy. In the present study, the following variables are used as X: number of graduate employees, firm size (small and medium), service sector dummies and a dummy for Eastern Germany. The average number of graduate employees of public subsidy recipients is bigger than that of the non-recipients.

Besides examining the full sample, the effect of government R\&D subsidy is also analyzed at different firm sizes (small, medium and large). As Kim et al. (2016) analyze the effect of R\&D activities on product innovation in Korean service sector and find 
that for product innovation internal R\&D activities are the most significant factors for large as well as small medium enterprise (SMEs). The same study also reveals that public funding programs have remarkable impact on product innovation but only in case of SMEs. Similarly, another Korean study investigate the effect of public financial support programs on innovation activities of SMEs and find that a significant relationship exists between public support programs and technological innovation (Doh et al., 2014). Bozic et al. (2016) compare the innovation determinants in manufacturing as well as service sector among small and medium sized firms in Croatia. The results suggest that R\&D matters for product innovation, however, firm size does not have any effect on both innovation types (i.e. product and process) in any of the sectors.

\section{Table 2}

Descriptive Statistics across Firm Size

\begin{tabular}{|c|c|c|c|c|c|c|c|c|c|c|c|c|}
\hline \multirow[t]{3}{*}{ Variables } & \multicolumn{4}{|c|}{$\begin{array}{c}\text { Small firms } \\
\text { (Less than } 50 \text { Employees) }\end{array}$} & \multicolumn{4}{|c|}{$\begin{array}{c}\text { Medium firms } \\
\text { (50 to } 250 \text { Employees) }\end{array}$} & \multicolumn{4}{|c|}{$\begin{array}{c}\text { Large firms } \\
\text { (more than } 250 \text { Employees) }\end{array}$} \\
\hline & \multicolumn{2}{|c|}{$\begin{array}{l}\text { Public funding } \\
\text { recipients }\end{array}$} & \multicolumn{2}{|c|}{ Non-recipients } & \multicolumn{2}{|c|}{$\begin{array}{l}\text { Public funding } \\
\text { recipients }\end{array}$} & \multicolumn{2}{|c|}{ Non-recipients } & \multicolumn{2}{|c|}{$\begin{array}{l}\text { Public funding } \\
\text { recipients }\end{array}$} & \multicolumn{2}{|c|}{ Non-recipients } \\
\hline & Mean & SD & Mean & SD & Mean & SD & Mean & SD & Mean & SD & Mean & SD \\
\hline $\begin{array}{l}\text { Marketing } \\
\text { Innovation }\end{array}$ & 0.500 & 0.502 & 0.296 & 0.457 & 0.571 & 0.501 & 0.276 & 0.448 & 0.571 & 0.514 & 0.339 & 0.478 \\
\hline $\begin{array}{l}\text { Organizational } \\
\text { Innovation }\end{array}$ & 0.533 & 0.501 & 0.268 & 0.443 & 0.762 & 0.431 & 0.368 & 0.484 & 0.692 & 0.48 & 0.455 & 0.503 \\
\hline $\begin{array}{l}\text { Copyright } \\
\text { Application }\end{array}$ & 0.197 & 0.399 & 0.070 & 0.255 & 0.179 & 0.389 & 0.029 & 0.168 & 0.364 & 0.505 & 0.020 & 0.140 \\
\hline $\begin{array}{l}\text { Graduated } \\
\text { Employees }\end{array}$ & 0.910 & 0.288 & 0.674 & 0.469 & 0.974 & 0.160 & 0.861 & 0.347 & 1.000 & 0.000 & 0.962 & 0.194 \\
\hline $\begin{array}{l}\text { National } \\
\text { Market }\end{array}$ & 0.874 & 0.333 & 0.605 & 0.489 & 0.865 & 0.347 & 0.562 & 0.498 & 0.833 & 0.389 & 0.574 & 0.500 \\
\hline $\begin{array}{l}\text { Eastern } \\
\text { Germany }\end{array}$ & 0.625 & 0.486 & 0.391 & 0.488 & 0.381 & 0.492 & 0.385 & 0.488 & 0.143 & 0.363 & 0.214 & 0.414 \\
\hline Wholesale & 0.044 & 0.206 & 0.117 & 0.321 & 0.024 & 0.154 & 0.109 & 0.313 & 0.000 & 0.000 & 0.107 & 0.312 \\
\hline $\begin{array}{l}\text { Transport/Post } \\
\text { Services }\end{array}$ & 0.051 & 0.222 & 0.238 & 0.426 & 0.143 & 0.354 & 0.340 & 0.475 & 0.214 & 0.426 & 0.321 & 0.471 \\
\hline $\begin{array}{l}\text { Media } \\
\text { Services }\end{array}$ & 0.059 & 0.236 & 0.065 & 0.246 & 0.071 & 0.261 & 0.064 & 0.246 & 0.000 & 0.000 & 0.036 & 0.187 \\
\hline IT Services & 0.279 & 0.450 & 0.049 & 0.216 & 0.167 & 0.377 & 0.058 & 0.234 & 0.286 & 0.469 & 0.018 & 0.134 \\
\hline $\begin{array}{l}\text { Financial } \\
\text { Services }\end{array}$ & 0.007 & 0.086 & 0.068 & 0.251 & 0.024 & 0.154 & 0.083 & 0.277 & 0.071 & 0.267 & 0.232 & 0.426 \\
\hline $\begin{array}{l}\text { Technical } \\
\text { Services }\end{array}$ & 0.456 & 0.500 & 0.180 & 0.384 & 0.524 & 0.505 & 0.051 & 0.221 & 0.286 & 0.469 & 0.018 & 0.134 \\
\hline $\begin{array}{l}\text { Business } \\
\text { Services }\end{array}$ & 0.044 & 0.206 & 0.109 & 0.311 & 0.048 & 0.216 & 0.250 & 0.434 & 0.143 & 0.363 & 0.232 & 0.426 \\
\hline Sample Size & & & & & & & & & & & & \\
\hline
\end{tabular}

Source: Authors' work

\section{Results}

The findings by the application of probit regression showing the impact of different variables is provided in Table 3. More specifically, Table 3 provides findings for marketing and organizational innovation across different firm sizes (small, medium and large). It can be seen that the impact of government R\&D subsidy on marketing and organizational innovation is positive and highly significant in small as well as in medium sized firms. This result indicates that in small and medium firm's subsidy significantly increases the likelihood that a firm performs marketing and organizational innovation. In case of large firms, it has an opposite but insignificant sign. The positive sign for large firms can be attributed to several reasons. One probable reason can be that the total number of firms among the large firms that receive subsidy is very low as compared to large firms that do not receive any subsidy (see Table 2, only 14 firms receive 
subsidy). Thus, the impact of subsidy may get diluted by the non-subsidized firms. In addition, graduate employees in small firms and media services in medium firms are positively associated with marketing and organizational innovation. The $p$-value of LR statistics is less than 1\%, suggesting that all variables are jointly significant as well, both in small and medium firms. Thus, the first hypothesis holds for small and medium firms but it doesn't hold for large firms.

These empirical findings are broadly in line with previous literature finding positive impacts of public R\&D subsidy on product and/or process innovation (for instance, Czarnitzki et al., 2011; Kim et al., 2016; Bérubé et al., 2009). The empirical findings are in contrast with Bozic et al. (2016) showing that R\&D matters for product innovation but firm size has no influence on both types of innovations in the manufacturing and service sector. In contrast, in this study, firm size matters. Further, Bozic et al. (2016) elaborate that marketing innovations are less likely to introduce in services firms that operating in technology intensive sector and new services are more likely to promote in service sector. However, our results suggest that small as well as medium service firms are more likely to introduce new marketing and organizational innovation).

Table 3

Estimation Results of Probit Model among Firm Size

\begin{tabular}{|c|c|c|c|c|c|c|}
\hline \multicolumn{3}{|c|}{$\begin{array}{c}\text { Small firms } \\
\text { (Less than } 50 \text { Employees) }\end{array}$} & \multicolumn{2}{|c|}{$\begin{array}{c}\text { Medium firms } \\
\text { (50 to } 250 \text { Employees) }\end{array}$} & \multicolumn{2}{|c|}{$\begin{array}{c}\text { Large firms } \\
\text { (more than } 250 \text { Employees) }\end{array}$} \\
\hline & $\begin{array}{l}\text { Marketing } \\
\text { Innovation }\end{array}$ & $\begin{array}{l}\text { Organizational } \\
\text { Innovation }\end{array}$ & $\begin{array}{l}\text { Marketing } \\
\text { Innovation }\end{array}$ & $\begin{array}{l}\text { Organizational } \\
\text { Innovation }\end{array}$ & $\begin{array}{l}\text { Marketing } \\
\text { innovation }\end{array}$ & $\begin{array}{l}\text { Organizational } \\
\text { innovation }\end{array}$ \\
\hline Variables & Coef. & Coef. & Coef. & Coef. & Coef. & Coef. \\
\hline Subsidy & $\begin{array}{l}0.560^{* * *} \\
(0.146)\end{array}$ & $\begin{array}{l}0.620^{* * *} \\
(0.146)\end{array}$ & $\begin{array}{l}0.919 * * * \\
(0.333)\end{array}$ & $\begin{array}{l}0.821^{* *} \\
(0.327)\end{array}$ & $\begin{array}{r}-0.0211 \\
(0.932)\end{array}$ & $\begin{array}{l}0.205 \\
(1.060)\end{array}$ \\
\hline $\begin{array}{l}\text { Graduate } \\
\text { Employees }\end{array}$ & $\begin{array}{l}0.356^{* * *} \\
(0.132)\end{array}$ & $\begin{array}{l}0.441^{* * *} \\
(0.138)\end{array}$ & $\begin{array}{c}0.507 \\
(0.409)\end{array}$ & $\begin{array}{c}0.550 \\
(0.381)\end{array}$ & - & - \\
\hline $\begin{array}{l}\text { National } \\
\text { Market }\end{array}$ & $\begin{array}{c}0.063 \\
(0.116)\end{array}$ & $\begin{array}{l}0.196^{*} \\
(0.119)\end{array}$ & $\begin{array}{c}0.091 \\
(0.263)\end{array}$ & $\begin{array}{c}0.234 \\
(0.251)\end{array}$ & $\begin{array}{l}-0.567 \\
(0.491)\end{array}$ & $\begin{array}{l}-0.888 \\
(0.561)\end{array}$ \\
\hline $\begin{array}{l}\text { Eastern } \\
\text { Germany }\end{array}$ & $\begin{array}{c}0.033 \\
(0.108)\end{array}$ & $\begin{array}{c}0.114 \\
(0.111)\end{array}$ & $\begin{array}{c}0.029 \\
(0.239)\end{array}$ & $\begin{array}{l}-0.011 \\
(0.235)\end{array}$ & $\begin{array}{c}0.229 \\
(0.471)\end{array}$ & $\begin{array}{c}0.684 \\
(0.524)\end{array}$ \\
\hline $\begin{array}{l}\text { Transport/Pos } \\
\text { † Service }\end{array}$ & $\begin{array}{l}0.305^{*} \\
(0.162)\end{array}$ & $\begin{array}{l}-0.084 \\
(0.168)\end{array}$ & $\begin{array}{c}0.192 \\
(0.359)\end{array}$ & $\begin{array}{c}0.293 \\
(0.342)\end{array}$ & $\begin{array}{l}-0.616 \\
(0.655)\end{array}$ & $\begin{array}{c}0.542 \\
(0.675)\end{array}$ \\
\hline $\begin{array}{l}\text { Media } \\
\text { Services }\end{array}$ & $\begin{array}{l}-0.071 \\
(0.228)\end{array}$ & $\begin{array}{c}0.084 \\
(0.232)\end{array}$ & $\begin{array}{l}1.230 * * \\
(0.553)\end{array}$ & $\begin{array}{l}1.017^{*} \\
(0.549)\end{array}$ & - & - \\
\hline IT Services & $\begin{array}{l}-0.247 \\
(0.205)\end{array}$ & $\begin{array}{l}-0.029 \\
(0.210)\end{array}$ & $\begin{array}{c}0.390 \\
(0.500)\end{array}$ & $\begin{array}{l}-0.090 \\
(0.491)\end{array}$ & $\begin{array}{c}0.774 \\
(1.126)\end{array}$ & - \\
\hline $\begin{array}{l}\text { Financial } \\
\text { Services }\end{array}$ & $\begin{array}{l}-0.370 \\
(0.240)\end{array}$ & $\begin{array}{l}0.473^{* *} \\
(0.227)\end{array}$ & $\begin{array}{c}0.636 \\
(0.552)\end{array}$ & $\begin{array}{c}0.433 \\
(0.544)\end{array}$ & $\begin{array}{l}-0.716 \\
(0.761)\end{array}$ & $\begin{array}{l}-0.550 \\
(0.818)\end{array}$ \\
\hline $\begin{array}{l}\text { Technical } \\
\text { Services }\end{array}$ & $\begin{array}{c}-0.486^{* * *} \\
(0.157)\end{array}$ & $\begin{array}{c}-0.317^{* *} \\
(0.160)\end{array}$ & $\begin{array}{l}-0.429 \\
(0.463)\end{array}$ & $\begin{array}{c}0.303 \\
(0.458)\end{array}$ & $\begin{array}{l}-0.199 \\
(1.079)\end{array}$ & $\begin{array}{c}0.141 \\
(1.175)\end{array}$ \\
\hline $\begin{array}{l}\text { Business } \\
\text { Services }\end{array}$ & $\begin{array}{c}0.133 \\
(0.194)\end{array}$ & $\begin{array}{c}0.256 \\
(0.201)\end{array}$ & $\begin{array}{c}0.054 \\
(0.418)\end{array}$ & $\begin{array}{c}0.120 \\
(0.400)\end{array}$ & $\begin{array}{l}-1.022 \\
(0.735)\end{array}$ & $\begin{array}{l}-0.064 \\
(0.772)\end{array}$ \\
\hline Constant & $\begin{array}{c}-0.627^{* * *} \\
(0.146)\end{array}$ & $\begin{array}{c}-1.051^{* * *} \\
(0.157)\end{array}$ & $\begin{array}{c}-1.283^{* *} \\
(0.534)\end{array}$ & $\begin{array}{l}-1.163^{* *} \\
(0.506)\end{array}$ & $\begin{array}{c}0.530 \\
(0.721)\end{array}$ & $\begin{array}{c}0.325 \\
(0.787)\end{array}$ \\
\hline $\begin{array}{l}\text { LR statistics } \\
\text { (p-value) }\end{array}$ & $\begin{array}{c}40.84 \\
(0.000)\end{array}$ & $\begin{array}{l}56.61 \\
(0.000)\end{array}$ & $\begin{array}{l}23.36 \\
0.010\end{array}$ & $\begin{array}{l}24.01 \\
0.008\end{array}$ & $\begin{array}{c}6.73 \\
0.566\end{array}$ & $\begin{array}{l}7.12 \\
0.416\end{array}$ \\
\hline Pseudo $\mathbf{R}^{2}$ & 0.048 & 0.069 & 0.119 & 0.115 & 0.102 & 0.120 \\
\hline Log likelihood & -401.808 & -383.240 & -86.606 & -92.101 & -29.769 & -26.233 \\
\hline Observations & 657 & 651 & 152 & 151 & 49 & 43 \\
\hline
\end{tabular}

Note: Standard errors are in parentheses; ${ }^{* * *},{ }^{* *}$ and $*$ respectively denote significance at $1 \%$, $5 \%$ and $10 \%$ significance level

Source: Authors' work 


\section{Empirical Results}

Tables 4 and 5 present the estimation results from matching methods (kernel and nearest neighbor and radius). In table 4 the first part shows the results from kernel matching and the middle part displays the K-nearest neighbor matching method results. Finally, the last part describes the findings of radius matching, whereas unmatched explains the difference in marketing and organizational innovation between non-recipients and recipients before matching and ATT lestimated via propensity score matching) shows the average treatment effect in the treated observations.

\section{Table 4}

Treatment Effects of Subsidy on Marketing and Organizational Innovation (Small Firms)

\begin{tabular}{|c|c|c|c|c|c|c|c|}
\hline & $\begin{array}{l}\text { Output } \\
\text { Variables }\end{array}$ & Sample & Treated & Controls & Difference & S.E. & $\begin{array}{l}t- \\
\text { value }\end{array}$ \\
\hline \multirow[t]{4}{*}{ Kernel } & $\begin{array}{l}\text { Marketing } \\
\text { innovation }\end{array}$ & Unmatched & 0.508 & 0.298 & 0.210 & 0.047 & 4.51 \\
\hline & & $A T T$ & 0.508 & 0.281 & 0.227 & 0.061 & 3.72 \\
\hline & $\begin{array}{l}\text { Organizational } \\
\text { innovation }\end{array}$ & Unmatched & 0.532 & 0.279 & 0.253 & 0.046 & 5.53 \\
\hline & & $A T T$ & 0.532 & 0.312 & 0.220 & 0.060 & 3.65 \\
\hline \multirow{4}{*}{$\begin{array}{l}\text { K- } \\
\text { Nearest } \\
\text { neighbor }\end{array}$} & $\begin{array}{l}\text { Marketing } \\
\text { innovation }\end{array}$ & Unmatched & 0.508 & 0.298 & 0.210 & 0.047 & 4.51 \\
\hline & & $A T T$ & 0.508 & 0.291 & 0.217 & 0.081 & 2.68 \\
\hline & $\begin{array}{l}\text { Organizational } \\
\text { innovation }\end{array}$ & Unmatched & 0.532 & 0.279 & 0.253 & 0.046 & 5.53 \\
\hline & & $A \pi T$ & 0.532 & 0.268 & 0.264 & 0.076 & 3.47 \\
\hline \multirow{4}{*}{ Radius } & $\begin{array}{l}\text { Marketing } \\
\text { innovation }\end{array}$ & Unmatched & 0.508 & 0.298 & 0.210 & 0.047 & 4.51 \\
\hline & & $A T T$ & 0.508 & 0.281 & 0.227 & 0.061 & 3.73 \\
\hline & $\begin{array}{l}\text { Organizational } \\
\text { innovation }\end{array}$ & Unmatched & 0.532 & 0.279 & 0.253 & 0.046 & 5.53 \\
\hline & & ATT & 0.532 & 0.310 & 0.222 & 0.060 & 3.68 \\
\hline
\end{tabular}

Source: Authors' work

The fourth column of Table 4 shows the average of marketing and organizational innovation which receive the treatment (subsidized firms) while the fifth column exhibits the control group (non-subsidized). The sixth column presents the difference among fourth and fifth column while the seventh column contains standard error of the differences. Whereas, the t-value for the equivalence of difference in average among two groups are presented in the last column.

Overall, subsidy has a significant as well as positive effect on marketing innovation for small and medium sized firms. Since the number of subsidized firms is low for large firms (only 14 firms have received subsidy), so the overall impact of subsidized firms gets diluted in case of large firms. The results of kernel, nearest neighbor and radius matching suggest that the effect of subsidy on marketing and organizational innovation is positive and significant for small firms while in case of medium firms this is true only for organizational innovation.

In sum, selection bias is corrected through propensity score matching methods (i.e., kernel and nearest neighbor and radius). In all matching methods the estimated average treatment effect on treated (ATTs) is statistically significant and positive for 
the case of small firms for both marketing and organizational innovation, whereas in case of medium firms this again holds for organizational innovation only. These results imply that R\&D subsidy effects vary with the firm size. Similarly, results are in line with Bronzini et al. (2016), revealing that in small firms R\&D support program has remarkable effect on the number of patenting applications in subsidized firms. In addition, empirical results are in line with Le et al. (2016) indicating that public R\&D grant reception has differential effect in small to medium firms.

Table 5

Treatment Effects of Subsidy on Marketing and Organizational Innovation (Medium Firms)

\begin{tabular}{|c|c|c|c|c|c|c|c|}
\hline & $\begin{array}{l}\text { Output } \\
\text { Variables }\end{array}$ & Sample & Treated & Controls & Difference & S.E. & $\begin{array}{l}t- \\
\text { value }\end{array}$ \\
\hline \multirow[t]{4}{*}{ Kernel } & $\begin{array}{l}\text { Marketing } \\
\text { innovation }\end{array}$ & Unmatched & 0.571 & 0.276 & 0.296 & 0.089 & 3.32 \\
\hline & & ATT & 0.571 & 0.488 & 0.083 & 0.149 & 0.56 \\
\hline & $\begin{array}{l}\text { Organizational } \\
\text { innovation }\end{array}$ & Unmatched & 0.743 & 0.371 & 0.372 & 0.092 & 4.06 \\
\hline & & ATT & 0.743 & 0.274 & 0.469 & 0.152 & 3.08 \\
\hline \multirow[t]{4}{*}{$\begin{array}{l}\text { Ke- } \\
\text { Nearest } \\
\text { neighbor }\end{array}$} & $\begin{array}{l}\text { Marketing } \\
\text { innovation }\end{array}$ & Unmatched & 0.571 & 0.276 & 0.296 & 0.089 & 3.32 \\
\hline & & ATT & 0.571 & 0.367 & 0.204 & 0.136 & 1.50 \\
\hline & $\begin{array}{l}\text { Organizational } \\
\text { innovation }\end{array}$ & Unmatched & 0.743 & 0.371 & 0.372 & 0.092 & 4.06 \\
\hline & & ATT & 0.743 & 0.331 & 0.412 & 0.135 & 3.06 \\
\hline \multirow{4}{*}{ Radius } & $\begin{array}{l}\text { Marketing } \\
\text { innovation }\end{array}$ & Unmatched & 0.571 & 0.276 & 0.296 & 0.089 & 3.32 \\
\hline & & ATT & 0.571 & 0.512 & 0.060 & 0.146 & 0.41 \\
\hline & $\begin{array}{l}\text { Organizational } \\
\text { innovation }\end{array}$ & Unmatched & 0.743 & 0.371 & 0.372 & 0.092 & 4.06 \\
\hline & & ATT & 0.743 & 0.298 & 0.444 & 0.149 & 2.99 \\
\hline
\end{tabular}

Source: Authors' work

\section{Test of Balancing Property}

As explained in section 3 above, one must check that the means of covariates should not differ statistically significant from the zero among recipient as well as non-recipient groups. Matching estimates can be considered as reliable if the means of covariates do not differ significantly.

Table 6 presents the mean covariates of every group before and after matching, and in addition it provides the t-test for mean sample values across the two groups along with the corresponding p-value. Most importantly, among recipient as well as non-recipient, before matching (the unmatched), the means of many covariates differ statistically. In the unmatched case, the findings show that in both groups (treated as well as control groups) usually do not have the same characteristics. However, after matching (in all methods), the mean difference among non-recipients and recipients is equal in all covariates, lending support to the null hypothesis of equality of means across the two groups. 
Table 6

Test for Matching Covariates via Balancing Property: Test Statistics

\begin{tabular}{|c|c|c|c|c|c|c|c|c|c|c|c|c|c|}
\hline & & \multicolumn{4}{|c|}{ Kernel } & \multicolumn{4}{|c|}{$K$ nearest neighbour } & \multicolumn{4}{|c|}{ Radius } \\
\hline \multirow[t]{2}{*}{ Variables } & & \multicolumn{2}{|c|}{ Mean } & \multicolumn{2}{|c|}{ t-test } & \multicolumn{2}{|c|}{ Mean } & \multicolumn{2}{|c|}{ t-test } & \multicolumn{2}{|c|}{ Mean } & \multicolumn{2}{|c|}{ t-test } \\
\hline & & 8 & $\begin{array}{l}\Omega \\
\stackrel{\rho}{\rho} \\
\underline{\overrightarrow{1}}\end{array}$ & + & 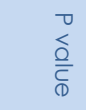 & $\begin{array}{l}\overrightarrow{\vec{D}} \\
\stackrel{\Omega}{\vec{D}} \\
\stackrel{\vec{D}}{\Omega} \\
\stackrel{\Omega}{0}\end{array}$ & $\begin{array}{l}\Omega \\
\stackrel{0}{2} \\
\underline{\bar{z}}\end{array}$ & + & 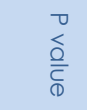 & 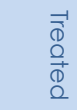 & $\begin{array}{l}? \\
\text { Oo } \\
\underline{\overline{1}} \\
\underline{0}\end{array}$ & + & $\begin{array}{l}\text { ○ } \\
\frac{\oint}{C} \\
\frac{\Phi}{D}\end{array}$ \\
\hline \multirow{2}{*}{$\begin{array}{l}\text { Graduate } \\
\text { Employees }\end{array}$} & $U$ & 0.924 & 0.714 & 5.870 & 0.000 & 0.924 & 0.714 & 5.870 & 0.000 & 0.924 & 0.714 & 5.870 & 0.000 \\
\hline & M & 0.931 & 0.908 & 0.750 & 0.456 & 0.931 & 0.933 & -0.060 & 0.950 & 0.931 & 0.901 & 0.960 & 0.337 \\
\hline \multirow{2}{*}{$\begin{array}{l}\text { National } \\
\text { Market }\end{array}$} & $U$ & 0.872 & 0.597 & 6.810 & 0.000 & 0.872 & 0.597 & 6.810 & 0.000 & 0.872 & 0.597 & 6.810 & 0.000 \\
\hline & M & 0.868 & 0.866 & 0.040 & 0.967 & 0.868 & 0.869 & -0.020 & 0.981 & 0.868 & 0.864 & 0.090 & 0.927 \\
\hline \multirow{2}{*}{$\begin{array}{l}\text { Eastern } \\
\text { Germany }\end{array}$} & $U$ & 0.567 & 0.390 & 4.370 & 0.000 & 0.567 & 0.390 & 4.370 & 0.000 & 0.567 & 0.390 & 4.370 & 0.000 \\
\hline & $M$ & 0.585 & 0.587 & -0.040 & 0.971 & 0.585 & 0.605 & -0.360 & 0.721 & 0.585 & 0.592 & -0.120 & 0.904 \\
\hline \multirow{2}{*}{$\begin{array}{l}\text { Transportation } \\
\text { Services }\end{array}$} & $U$ & 0.073 & 0.259 & -5.430 & 0.000 & 0.073 & 0.259 & -5.430 & 0.000 & 0.073 & 0.259 & -5.430 & 0.000 \\
\hline & M & 0.063 & 0.071 & -0.300 & 0.764 & 0.063 & 0.067 & -0.160 & 0.872 & 0.063 & 0.071 & -0.290 & 0.771 \\
\hline \multirow{2}{*}{$\begin{array}{l}\text { Media } \\
\text { Services }\end{array}$} & U & 0.062 & 0.064 & -0.090 & 0.925 & 0.062 & 0.064 & -0.090 & 0.925 & 0.062 & 0.064 & -0.090 & 0.925 \\
\hline & M & 0.057 & 0.046 & 0.410 & 0.680 & 0.057 & 0.051 & 0.210 & 0.832 & 0.057 & 0.042 & 0.590 & 0.553 \\
\hline \multirow[t]{2}{*}{ It Services } & U & 0.253 & 0.051 & 8.910 & 0.000 & 0.253 & 0.051 & 8.910 & 0.000 & 0.253 & 0.051 & 8.910 & 0.000 \\
\hline & $M$ & 0.264 & 0.291 & -0.530 & 0.596 & 0.264 & 0.264 & 0.000 & 1.000 & 0.264 & 0.294 & -0.590 & 0.556 \\
\hline \multirow{2}{*}{$\begin{array}{l}\text { Finance } \\
\text { Services }\end{array}$} & U & 0.011 & 0.069 & -2.970 & 0.003 & 0.011 & 0.069 & -2.970 & 0.003 & 0.011 & 0.069 & -2.970 & 0.003 \\
\hline & $M$ & 0.013 & 0.019 & -0.430 & 0.667 & 0.013 & 0.013 & 0.000 & 1.000 & 0.013 & 0.019 & -0.470 & 0.641 \\
\hline \multirow{2}{*}{$\begin{array}{l}\text { Technical } \\
\text { Services }\end{array}$} & U & 0.472 & 0.153 & 9.860 & 0.000 & 0.472 & 0.153 & 9.860 & 0.000 & 0.472 & 0.153 & 9.860 & 0.000 \\
\hline & $M$ & 0.465 & 0.438 & 0.500 & 0.620 & 0.465 & 0.462 & 0.060 & 0.949 & 0.465 & 0.435 & 0.550 & 0.585 \\
\hline \multirow{2}{*}{$\begin{array}{l}\text { Business } \\
\text { Services }\end{array}$} & U & 0.045 & 0.138 & -3.450 & 0.001 & 0.045 & 0.138 & -3.450 & 0.001 & 0.045 & 0.138 & -3.450 & 0.001 \\
\hline & $M$ & 0.050 & 0.047 & 0.150 & 0.884 & 0.050 & 0.049 & 0.040 & 0.971 & 0.050 & 0.052 & -0.080 & 0.936 \\
\hline
\end{tabular}

Source: Authors' work

Note: U: represent unmatched group, while $M$ : present the matched group

Table 7 reports the results of mean and median biases (before and after matching using all matching methods) along with some additional statistics including pseudo $\mathrm{R}^{2}$ and LR statistic for joint significance along with its $p$-value. It can be noted that, after matching, the mean as well as the median bias decrease considerably in all matching methods. Since pseudo $R^{2}$ is very close to zero, the matching may be considered as successful. The $p$-value of LR statistic is also zero lending support to a successful matching.

Overall, these statistical findings strongly support the validity of propensity score matching results reported. 
Table 7

Matching Covariates through Balancing Property: Joint Significance Test

\begin{tabular}{lcccc}
\hline & Before & \multicolumn{3}{c}{ After } \\
\hline & & Kernel & K- Nearest neighbour & Radius \\
Mean Bias & 44.9 & 3.6 & 1.0 & 4.2 \\
Med Bias & 51.5 & 3.1 & 0.5 & 3.4 \\
Pseudo R & 0.232 & 0.003 & 0.001 & 0.005 \\
LR test p-value & 0.000 & 0.998 & 1.000 & 0.990 \\
LR chi2 & 186.49 & 1.36 & 0.28 & 2.06 \\
\hline
\end{tabular}

Source: Authors' work

\section{Effects of Marketing and Organizational Innovation on Firm Performance}

This section provides results and discussion related to the second hypothesis presented in Table 8. The estimation is done by employing Probit regression and developing several models (Model 1-6) with and without using control variables to see the detailed and clear picture of the results. This hypothesis requires to shift focus only to those firms that have received subsidy. For this, firm performance is considered as a dependent variable measured via copyright-proxy for firm performance-a categorical variable that takes a value of ' 1 ' if firm uses a copyright application and zero who did not use copyright application. The independent variables include marketing and organizational innovation along with various controls (see Table 1). Since the dependent variable is categorical, so the probit model is ideal in the present situation. It is important to note that these regressions (Model 1-6) use aggregate data (combining observations for small and medium firms) and we do not run regressions separately for small and medium firms, as earlier done in case of first hypothesis. If the focus is on estimating two separate regressions (one each for small and medium firms) then there exists multicollinearity between various categories of control variables, taking either a value ' 1 ' or ' 0 ' throughout or in most cases. This makes the estimation of the coefficient for the particular dummy variable impossible. Thus, technically, it is not possible to estimate regressions separately for small and medium firms. In addition, the case of large firms is also not considered here due to the small number of observations.

Table 8 presents the results for the second hypothesis. Here again, probit regression model is used to estimate the effect of marketing and organizational innovation on copyright-used as a proxy to measure firm performance. The Model $1-3$ in Table 8 report the results without including control variables while Model 4-6 provides the findings including controls. More specifically, Model 1 considers the effect of marketing innovation on firm performance only, Model 2 analyzes the effect of organizational innovation on firm performance only, and Model 3 estimates the impacts of both, marketing and organizational innovation on firm performance. Model 4-6 work in parallel to Model $1-3$ but do not include control variables. Overall, Model 6 is a more general model as it analyzes the impact of both, marketing and organizational innovation and all control variables on firm performance.

The empirical findings based on Model 1, 3, 4 and 6 suggest a positive and significant effect of marketing innovation on firm performance since $p$-value is less than $1 \%$ in all cases. In addition, the coefficient of organizational innovation is also found to be positive and significant (Model 2 and 5). However, it is insignificant in Model 6, where all control variables are added too. The pseudo R2 is reasonable for the model with controls suggesting a relatively better fit that the models without control variables. The $\mathrm{p}$-value of LR statistic is zero to three decimal places in all models 
suggesting the joint significance of the regressors (Model 3-6). These findings suggest that $\mathrm{H}_{2}$ is supported in case of marketing innovation only. It is important to note that organizational innovation is found to be significant when taken individually (Model 2 and 5), however, its impact on firm performance gets diluted when both types of marketing and organizational innovations are considered together.

The empirical findings of this study are consistent with previous studies that also support the idea that all types of innovations (product, process, marketing and organizational) are (more or less) positively and significantly linked with some aspect of firm performance in manufacturing firms (Gunday et al., 2011). However, the empirical results are in contrast with Atalay et al. (2013) who show that marketing and organizational innovation do not have a positive (and significant) influence on firm performance in case of the automotive industry.

In sum, the results suggest that marketing innovations are more likely and organizational innovations are less likely to stimulate the firm performance in the service sector.

Table 8

Probit Estimation on Copyright Application (various specification)

\begin{tabular}{|c|c|c|c|c|c|c|}
\hline & Model 1 & Model 2 & Model 3 & Model 4 & Model 5 & Model 6 \\
\hline $\begin{array}{l}\text { Marketing } \\
\text { Innovation }\end{array}$ & $\begin{array}{c}0.821^{* * *} \\
(0.172)\end{array}$ & - & $\begin{array}{c}0.782^{* * *} \\
(0.182)\end{array}$ & $\begin{array}{c}0.713^{* * *} \\
(0.209)\end{array}$ & - & $\begin{array}{c}0.664^{* * *} \\
(0.221)\end{array}$ \\
\hline $\begin{array}{l}\text { Organizational } \\
\text { Innovation }\end{array}$ & - & $\begin{array}{l}0.387^{* *} \\
(0.160)\end{array}$ & $\begin{array}{c}0.119 \\
(0.177)\end{array}$ & - & $\begin{array}{l}0.379 * \\
(0.197)\end{array}$ & $\begin{array}{c}0.168 \\
(0.213)\end{array}$ \\
\hline $\begin{array}{l}\text { Graduate } \\
\text { Employees }\end{array}$ & - & - & - & $\begin{array}{c}0.343 \\
(0.519)\end{array}$ & $\begin{array}{c}0.373 \\
(0.503)\end{array}$ & $\begin{array}{c}0.330 \\
(0.524)\end{array}$ \\
\hline $\begin{array}{l}\text { National } \\
\text { Market }\end{array}$ & - & - & - & $\begin{array}{c}0.417 \\
(0.280)\end{array}$ & $\begin{array}{l}0.506^{*} \\
(0.279)\end{array}$ & $\begin{array}{c}0.411 \\
(0.282)\end{array}$ \\
\hline $\begin{array}{l}\text { Eastern } \\
\text { Germany }\end{array}$ & - & - & - & $\begin{array}{c}0.043 \\
(0.192)\end{array}$ & $\begin{array}{c}0.076 \\
(0.190)\end{array}$ & $\begin{array}{c}0.072 \\
(0.194)\end{array}$ \\
\hline $\begin{array}{l}\text { Transport/Post } \\
\text { Services }\end{array}$ & - & - & - & $\begin{array}{l}-0.039 \\
(0.421)\end{array}$ & $\begin{array}{l}-0.157 \\
(0.412)\end{array}$ & $\begin{array}{l}-0.059 \\
(0.424)\end{array}$ \\
\hline $\begin{array}{l}\text { Media } \\
\text { Services }\end{array}$ & - & - & - & $\begin{array}{c}1.610 * * * \\
(0.370)\end{array}$ & $\begin{array}{c}1.697^{* * *} \\
(0.360)\end{array}$ & $\begin{array}{c}1.615^{* * *} \\
(0.370)\end{array}$ \\
\hline IT Services & - & - & - & $\begin{array}{c}1.028^{* * *} \\
(0.334)\end{array}$ & $\begin{array}{c}0.956^{* * *} \\
(0.322)\end{array}$ & $\begin{array}{c}1.030^{* * *} \\
(0.335)\end{array}$ \\
\hline $\begin{array}{l}\text { Finance } \\
\text { Services }\end{array}$ & - & - & - & $\begin{array}{l}-0.134 \\
(0.549)\end{array}$ & $\begin{array}{l}-0.064 \\
(0.543)\end{array}$ & $\begin{array}{l}-0.129 \\
(0.551)\end{array}$ \\
\hline $\begin{array}{l}\text { Technical } \\
\text { Services }\end{array}$ & - & - & - & $\begin{array}{l}0.745^{* *} \\
(0.348)\end{array}$ & $\begin{array}{l}0.551^{*} \\
(0.332)\end{array}$ & $\begin{array}{l}0.739 * * \\
(0.348)\end{array}$ \\
\hline $\begin{array}{l}\text { Business } \\
\text { Services }\end{array}$ & - & - & - & $\begin{array}{c}0.260 \\
(0.452)\end{array}$ & $\begin{array}{c}0.125 \\
(0.446)\end{array}$ & $\begin{array}{c}0.234 \\
(0.455)\end{array}$ \\
\hline $\begin{array}{l}\text { Wald-Statistic } \\
\text { (p-value) }\end{array}$ & 0.000 & 0.014 & 0.000 & 0.000 & 0.000 & 0.000 \\
\hline $\begin{array}{l}\text { Likelihood } \\
\text { function }\end{array}$ & -161.484 & -171.211 & -161.055 & -118.897 & -122.929 & -118.149 \\
\hline Pseudo R2 & 0.074 & 0.016 & 0.076 & 0.232 & 0.205 & 0.236 \\
\hline Obs. & 492 & 491 & 491 & 416 & 415 & 415 \\
\hline
\end{tabular}

Note: Standard errors are in parentheses; ${ }^{* * *},{ }^{* *}$ and ${ }^{*}$ respectively denote significance at $1 \%$, $5 \%$ and $10 \%$ significance level.

Source: Authors' work 


\section{Conclusion}

This paper considers the case of marketing and organizational innovation for the subsidized and non-subsidized firms. Particularly, the firms are subdivided into three categories depending upon the total number of employees (small, medium and large) and the impact of public subsidy is analyzed by comparing the marketing and organizational innovation between subsidy recipients and non-recipients. In addition, the paper covers the issue of marketing innovation and organizational innovation and their impact on copyright application-used as a proxy to measure firm performance. The empirical analysis is based on the micro data from Mannheim Innovation Panel Services (MIP) Germany. To our knowledge, this is the first study to analyze the effect of marketing as well as organizational innovation on firm performance (measured in terms of copyright applications). Thus, it fills an important gap in the existing literature.

The empirical findings reveal interesting results for the subsidized as well as nonsubsidized firms while focusing on small and medium firms.

Firstly, the basic summary statistics suggest that subsidized firms are more involved in marketing and organizational innovation than non-subsidized ones and this is found true for all types of firms (small, medium and large). However, reader should take into account, that we omit the large firms due to low number of observations, the overall impact of subsidized firms gets diluted in case of large firms (see details of subsidy recipients in Table 2) These results are further confirmed via probit regression as well. However, the results of probit regression show a positive impact for the subsidized firms, i.e., these firms are more involved in innovations of both types (organizational as well as marketing). Moreover, these results are found to be significant for small and medium firms.

To avoid the selection bias, propensity score matching is used and in particular, three popular methods-kernel, nearest neighbor matching and radius matching are used to carry out the empirical analysis. The results of kernel matching, nearest neighbor and radius matching suggest that the impact of subsidy on marketing and organizational innovation is positive as well as significant for the small firms, while in case of medium firms, all matching methods show positive and significant effects of subsidy on organizational innovation.

Secondly, the impact of marketing and organizational innovation on firms' performance taking copyrights as proxy is also analyzed for small and medium firms via probit regression. The empirical findings suggest that the impact of both, marketing and organizational innovation, is highly significant on the performance of small and medium sized firms.

Further, the empirical findings for both types of innovation (Model 1-6) suggest that marketing innovation has a highly significant impact on firm performance in the whole sample (combining both small and medium firms), while organizational innovation has less significant impact on firm performance.

All in all, the empirical findings suggest that public R\&D subsidy matters for marketing and organizational innovation in service firms and ultimately its effect on firm performance. In addition, the impact of public subsidy is found to be positive as well as significant on firm performance implying that the subsidized firms are more likely to perform better than their counterparts. Moreover, the results show that a public subsidy program is successful and it increases the probability of applying for a copyright in case of small and medium sized firms. Moreover, public subsidy also stimulates the marketing and organizational innovation in small and medium firms.

Based on empirical findings, it is recommended that the government should provide subsidy to firms of all sizes in the service sector especially to the small and medium sized ones to enhance the firm performance and to bring about innovation. 
The only limitation of the study is the unavailability of sufficient relevant data for the large firms that received subsidy. This can be addressed by using a panel data in a future research.

\section{References}

1. Albors-Garrigos, J., Barrera, R. R. (2011), "Impact of Public Funding on A Firm's Innovation Performance: Analysis of Internal and External Moderating Factors", International Journal of innovation management, Vol. 15, No. 6, pp. 1297-1322.

2. Almus, M., Czarnitzki, D. (2003), "The effects of public R\&D subsidies on firms' innovation activities: the case of Eastern Germany", Journal of Business \& Economic Statistics, Vol. 21, No. 2, pp. 226-236.

3. Arvanitis, S., Woerter, M. (2013), "Firm characteristics and the cyclicality of R\&D investments", Industrial and Corporate Change, Vol. 23, No. 5, pp. 1141-1169.

4. Atalay, M., Anafarta, N., Sarvan, F. (2013), "The relationship between innovation and firm performance: An empirical evidence from Turkish automotive supplier industry", ProcediaSocial and Behavioral Sciences, Vol. 75, pp. 226-235.

5. Becheikh, N., Landry, R., Amara, N. (2006), "Lessons from innovation empirical studies in the manufacturing sector: A systematic review of the literature from 1993-2003", Technovation, Vol. 26, No. 5-6, pp. 644-664.

6. Becker, W., Dietz, J. (2004), "R\&D cooperation and innovation activities of firms-evidence for the German manufacturing industry", Research policy, Vol. 33, No. 2, pp. 209-223.

7. Bérubé, C., Mohnen, P. (2009), "Are firms that receive R\&D subsidies more innovative?", Canadian Journal of Economics/Revue Canadienne d'économique, Vol. 42, No. 1, pp. 206-225.

8. Beugelsdijk, S., Cornet, M. (2002), "'A far friend is worth more than a good neighbor': proximity and innovation in a small country", Journal of Management and Governance, Vol. 6, No. 2, pp. 169-188.

9. Bozic, L., Mohnen, P. (2016), "Determinants of innovation in Croatian SMEs-comparison of service and manufacturing firms", Market/Tržište, Vol. 28, No. 1, pp. 7-27.

10. Branstetter, L. G., Sakakibara, M. (2002), "When do research consortia work well and why? Evidence from Japanese panel data", American Economic Review, Vol. 92, No. 1, pp. 143 159.

11. Bronzini, R., Piselli, P. (2016), "The impact of R\&D subsidies on firm innovation", Research Policy, Vol. 45, No. 2, pp. 442-457.

12. Buson Piquer, I. (1991), "Impacto de las ayudas públicas a las actividades de I+ D de las empresas: un análisis empírico", Herri ekonomiaz, No. 11, pp. 47-66.

13. Cainelli, G., Evangelista, R., Savona, M. (2004), "The impact of innovation on economic performance in services", The Service Industries Journal, Vol. 24, No. 1, pp. 116-130.

14. Caliendo, M., Kopeinig, S. (2008), "Some Practical Guidance for the Implementation of Propensity Score Matching", Journal of Economic Surveys, Vol. 22, No. 1, pp. 31-72.

15. Carboni, O. A. (2017), "The effect of public support on investment and R\&D: An empirical evaluation on European manufacturing firms", Technological Forecasting and Social Change, Vol. 117, pp. 282-295.

16. Cozza, C., Malerba, F., Mancusi, M. L., Perani, G., Vezzulli, A. (2012), „Innovation, profitability and growth in medium and high-tech manufacturing industries: evidence from Italy", Applied Economics, Vol. 44, No. 15, pp. 1963-1976.

17. Czarnitzki, D., Fier, A. (2001), "Do R\&D subsidies matter?-evidence for the German service sector", available at: ftp://ftp.zew.de/pub/zew-docs/dp/dp0119.pdf (10 January 2018)

18. Czarnitzki, D., Fier, A. (2002), "Do innovation subsidies crowd out private investment? Evidence from the German service sector", available at: ftp://ftp.zew.de/pub/zewdocs/dp/dp0204.pdf (10 January 2018)

19. Czarnitzki, D., Hanel, P., Rosa, J. M. (2011), "Evaluating the impact of R\&D tax credits on innovation: A microeconometric study on Canadian firms", Research Policy, Vol. 40, No. 2 , pp. 217-229. 
20. Czarnitzki, D., Licht, G. (2006), "Additionality of public R\&D grants in a transition economy", Economics of Transition, Vol. 14, No. 1, pp. 101-131.

21. Czarnitzki, D., Lopes-Bento, C. (2014), "Innovation subsidies: Does the funding source matter for innovation intensity and performance? Empirical evidence from Germany", Industry and Innovation, Vol. 21, No. 5, pp. 380-409.

22. Doh, S., Kim, B. (2014), "Government support for SME innovations in the regional industries: The case of government financial support program in South Korea", Research Policy, Vol. 43, No. 9, pp. 1557-1569.

23. Duchêne, V., Lykogianni, E., Verbeek, A. (2009), "EU-R\&D in Services Industries and the EUUS R\&D Investment Gap". available at: http://iri.jrc.ec.europa.eu/documents/10180/b218443f-8cf0-4c86-b25b-64dce0119ade (10 January 2018)

24. Elche, D. M., González, Á. (2008), „Influence of innovation on performance: analysis of Spanish service firms", The Service Industries Journal, Vol. 28, No. 10, pp. 1483-1499.

25. Fernández, E., Junquera, B., Vazquez, C. (1995), "La política de I + D en la empresa no financier", Información Comercial Espanola, Vol. 81, pp. 104-117.

26. Gunday, G., Ulusoy, G., Kilic, K., Alpkan, L. (2011), "Effects of innovation types on firm performance", International Journal of production economics, Vol. 133, No. 2, pp. 662-676.

27. Hall, B. H., Lotti, F., Mairesse, J. (2009), "Innovation and productivity in SMEs: empirical evidence for Italy", Small Business Economics, Vol. 33, No. 1, pp. 13-33.

28. Haned, N., Mothe, C., Nguyen-Thi, T. U. (2014), "Firm persistence in technological innovation: the relevance of organizational innovation", Economics of Innovation and New Technology, Vol. 23, No. 5-6, pp. 490-516.

29. Hanzl-Weiss, D., Stehrer, R. (2010), "The role of services in the new member states: a comparative analysis based on input-output tables", The Vienna Institute for International Economic Studies, No. 366.

30. Heckman, J. D., Ichimura, H., Todd P. E., (1997), "Matching as an Econometric Evaluation Estimator: Evidence from Evaluating a Job Training Programme", Review of Economic Studies, Vol. 64, No. 4, pp. 605-654.

31. Heckman, J. J., Ichimura, H., Todd, P. (1998), "Matching as an econometric evaluation estimator", The review of economic studies, Vol. 65, No. 2, pp. 261-294.

32. Herrera, L., Nieto, M. (2008), "The national innovation policy effect according to firm location", Technovation, Vol. 28, No. 8, pp. 540-550.

33. Hussinger, K. (2008), "R\&D and subsidies at the firm level: An application of parametric and semiparametric two-step selection models", Journal of applied econometrics, Vol. 23, No. 6, pp. 729-747.

34. Johne, A., Davies, R. (2000), "Innovation in medium-sized insurance companies: how marketing adds value", International Journal of Bank Marketing, Vol. 18, No. 1, pp. 6-14.

35. Keizer, J. A., Dijkstra, L., Halman, J. I. (2002), „Explaining innovative efforts of SMEs.: An exploratory survey among SMEs in the mechanical and electrical engineering sector in The Netherlands", Technovation, Vol. 22, No. 1, pp. 1-13.

36. Kim, S. J., Kim, E. M., Suh, Y., Zheng, Z. (2016), "The effect of service innovation on R\&D activities and government support systems: the moderating role of government support systems in Korea", Journal of Open Innovation: Technology, Market, and Complexity, Vol. 2, No. 5, pp. 1-13.

37. Lam, A. (2005), "Organizational Innovation", Fagerberg, J., Mowery, D. C., Nelson, R. R. (Eds), The Oxford Handbook of Innovation, Oxford University Press, Oxford, pp. 115-147.

38. Le, T., Jaffe, A. B. (2016), "The impact of R\&D subsidy on innovation: evidence from New Zealand firms", Economics of Innovation and New Technology, Vol. 26, No. 5, pp. 429-452.

39. Li, P., Wang, C. H. (2010), "The Nonlinear Study of Public S\&T Subsidies to Business Innovation: A Threshold Regression Analysis Based on Panel Data in 2001-2008", China Soft Science Magazine, Vol. 8, pp. 138-147.

40. Liu, R., Rammer, C. (2016), "The Contribution of Different Public Innovation Funding Programs to SMEs' Export Performance", available at: http://ftp.zew.de/pub/zewdocs/dp/dp16078.pdf (10 January 2018) 
41. Lokshin, B., Belderbos, R., Carree, M. (2008), "The productivity effects of internal and external R\&D: Evidence from a dynamic panel data model", Oxford bulletin of Economics and Statistics, Vol. 70, No. 3, pp- 399-413.

42. Otero-Neira, C., Tapio Lindman, M., Fernández, M. J. (2009), "Innovation and performance in SME furniture industries: An international comparative case study", Marketing Intelligence \& Planning, Vol. 27, No. 2, pp. 216-232.

43. Peters, B., Roberts, M. J., Vuong, V. A., Fryges, H. (2013). "Firm R\&D, Innovation, and Productivity in German Industry", Center for European Economic Research (ZEW).

44. Polder, M., Leeuwen, G. V., Mohnen, P., Raymond, W. (2010), „Product, process and organizational innovation: drivers, complementarity and productivity effects", MERIT Working Papers 035, United Nations University - Maastricht Economic and Social Research Institute on Innovation and Technology.

45. Reinkowski, J., Alecke, B., Mitze, T., Untiedt, G. (2010), „Effectiveness of Public R\&D Subsidies in East Germany-ls it a Matter of Firm Size?", available at: http://citeseerx.ist.psu.edu/viewdoc/download? doi=10.1.1.408.136\&rep=repl \&type=pdf (10 January 2018)

46. Rogers, M. (1998). The definition and measurement of productivity, Melbourne Institute of Applied Economic and Social Research.

47. Romer, P. (1989), "Endogenous technological change", Journal of Political Economy, Vol. 98, No. 5, pp. 71-102.

48. Romijn, H., Albaladejo, M. (2002), "Determinants of innovation capability in small electronics and software firms in southeast England", Research Policy, Vol. 31, No. 7, pp. 1053-1067.

49. Rosenbaum, P. R., Rubin, D. B. (1983), "The central role of the propensity score in observational studies for causal effects", Biometrika, Vol. 70, No. 1, pp. 41-55.

50. Rubin, D. (1974), "Estimating Causal Effects of Treatments in Randomized and Nonrandomized Studies", Journal of Educational Psychology, Vol. 66, No. 5, pp. 688-701.

51. Sandvik, I. L., Sandvik, K. (2003), "The impact of market orientation on product innovativeness and business performance", International journal of Research in Marketing, Vol. 20, No. 4, pp. 355-376.

52. Souitaris, V. (2002), "Technological trajectories as moderators of firm-level determinants of innovation", Research Policy, Vol. 31, No. 6, pp. 877-898.

53. Van Riel, A. C., Lemmink, J., Ouwersloot, H. (2004), "High-technology service innovation success: a decision-making perspective", Journal of Product Innovation Management, Vol. 21, No. 5, pp. 348-359.

54. Wang, Y., Li, J., Furman, J. L. (2017), „Firm performance and state innovation funding: Evidence from China's innofund program", Research Policy, Vol. 46, No. 6, pp. 1142-1161. 


\section{About the authors}

Shoaib Abdul Basit, M.Sc. is a PhD student at Faculty of Economics and Business Administration, Technische Universität Chemnitz, Germany. He received M.Sc. degree in economics with specialization in "Innovation and Change" at Friedrich Schiller University Jena, Germany. He Participated in 10th summer school on "Innovation and Uncertainty" Jointly offered by Max Planck Institute of Economics Jena and Friedrich Schiller University of Jena, Germany. He participated in workshops for academic writing and teaching in English at Center for Young Scientists at Technische Universität Chemnitz, Germany. He attended conference of International Schumpeter Society in FSU Jena, Germany. His main research interests lie in economics of innovation and industrial organization. Corresponding author can be contacted at: shoaibkherani_iivi@yahoo.com

Thomas Kuhn is a Professor of Public Finance at Faculty of Economics and Business Administration, Technische Universität Chemnitz, Germany. He has published papers in several journals such as International Journal of Global Environmental Issues, Journal of Evolutionary Economics, Resource and Energy Economics, Journal Public Finance, Procedia Economics and Finance, Review of International Economics, Review of Economic Design, Forschungsinstitut zur Zukunft der Arbeit (IZA) etc. He published textbooks and monographs: Volkswirtschaftslehre 1: Grundlegende Mikro- und Makroökonomik, 6 and Theorie des kommunalen Finanzausgleichs published by springer, Theorie des Kommunalen Finanzausgleichs - Allokative und distributive Aspekte as well as coauther in Einführung in die Volkswirtschaftslehre. Author can be contacted at: thomas.kuhn@wirtschaft.tu-chemnitz.de

Mumtaz Ahmed is an Assistant Professor at Department of Management Sciences, COMSATS Institute of Information Technology, Islamabad, Pakistan. He holds a PhD and a Post-Doc in Econometrics. He has a number of publications in top journal like Economic Modelling, Communications in Statistics-Theory and Methods, Empirical Economics. His main research interest areas include Information Theoretic Methods in Econometrics and Energy Economics. Author can be contacted at: mumtaz.ahmed@comsats.edu.pk 